Research article

\title{
Mineral Content and Magnetic Properties of River Iron Sand from Jayapura, Papua
}

\author{
Endang Haryati, Khaeriah Dahlan, Martina Bunga, Daniel Napitupulu, Octolia Togibasa* \\ Department of Physics, Universitas Cenderawasih, Jayapura 99358, Indonesia
}

\section{Article info}

\section{Keywords:}

Iron sand

Mineral content

Magnetic properties

Magnetite

Soft magnetic

\begin{abstract}
In this study, we investigated the mineral content and magnetic properties of river iron sand from Jayapura, Papua. The iron sand was collected from the Waimbow River in the Waibu District, whereas the bulk samples were extracted using a permanent magnet. The extracted iron sand was characterized using X-ray fluorescence and X-ray diffractometer to identify the elemental composition and structural phase. Meanwhile, the vibrating sample magnetometer was also applied to characterize the magnetic properties. The results show that the iron sand contains magnetite as a major mineral, with soft magnetic properties. The hysteresis curve shows that the iron sand has a high saturation magnetization of $27.8 \mathrm{emu} / \mathrm{g}$, remanent magnetization of $2.34 \mathrm{emu} / \mathrm{g}$, and coercive field of $21.3 \mathrm{Oe}$. These results also indicate that the iron sand formation in northern Papua was mainly due to lithogenic factors.
\end{abstract}

\section{Introduction}

Iron sand is one of Indonesia's high potential mineral resources, with an amount that can reach up to 160 million tons, scattered across the coastal and rivers, from Sumatera to Papua [1]. Iron sand contains iron ore which is commonly in the form of hematite, magnetite, maghemite, oxides or carbonates, namely siderite and calibit [2]. Furthermore, iron sand exhibit magnetic properties, which may vary and even increase significantly with just simple treatment, such as magnetic extraction [3] and grain size variation [4]. Due to its attractive mineral and magnetic properties, many efforts have made to make iron sand more economically valuable, no longer just as a basic building material. Ceramic permanent magnets [5], magnetic nanoparticles [6], color pigments [7], and other material are some examples. Therefore, research on iron sands characterization becomes important.

Previously, exploration of the characterization of iron sands in Indonesia focused mostly on Sumatera and Java. This is reasonable, since a significant number of volcanoes lie within Sumatera and Java and influence the high distribution of iron sand in the area. A comparative study of iron sand characteristic from several area in Java revealed that magnetite, hematite, and ilmenite mineral were present, with relatively high mass-specific magnetic susceptibility values ranging from $1 \times 10^{-4} \mathrm{~m}^{3} / \mathrm{kg}$ to $3 \times 10^{-4} \mathrm{~m}^{3} / \mathrm{kg}$ [5, 8]. Another study confirmed that the iron sand deposit in Java was derived from denudation of andesite and old andesite formation enriched in magnetite and ilmenite minerals [9]. Several studies of iron sand from Sumatera revealed the magnetite minerals were also dominant, hence lower magnetic properties [10, 11].

The iron sands in Papua have begun to attract attention nowadays, in particular on the north coast of Papua. Our previous studies focused on the iron sand from the coastal areas in Sarmi Regency [12-15]. The natural iron sand in Sarmi revealed that hematite and magnetite mineral were dominant [13], and they could be useful as a concrete raw material for nuclear protective walls [14]. Interestingly, the magnetic extract of iron sand from the Tor river estuary showed a magnesioferrite $\left(\mathrm{MgFe}_{2} \mathrm{O}_{4}\right)$ mineral with a higher mass-specific magnetic susceptibility value of $2.7 \times 10^{-4} \mathrm{~m}^{3} / \mathrm{kg}$ and a superparamagnetic behavior, suggesting a widespread application in microwave devices. However, the existence of iron sand in northern region of Papua is still occasional since the absence of an active volcano in these areas.

The river plays an important role in Papua, not just for domestic but also for economic activities [16]. The rapid development in Jayapura, Papua, has led to a high level of river sand mining in the area. The Waibu district, in Jayapura Regency, has been known to have a busy C-class mining activity [17]. Unfortunately, uncontrolled river sand mining can cause environmental problems [18]. Furthermore, the use of iron sand from rivers for industrial applications will certainly be more profitable than for concrete material. In this study we investigated iron sand from rivers from northern region of Papua, particularly Jayapura Regency. The purpose of this research is to provide information on the mineral, structural properties, and magnetic properties of river iron sand, in order to determine the potential for more profitable applications.

\section{Experimental Methods}

The iron sand was collected from Waimbow River, Waibu District, Jayapura Regency, Papua Province, located around 2³3’11.2" S dan $140^{\circ} 27^{\prime} 23.1^{\prime \prime}$ E, as shown in Figure 1. The collected iron sand was washed with distilled water to remove the sea water content and then proceed with natural drying under the sun. Subsequently, the sample was crushed using a grinder and mortar to be further extracted using a permanent magnet. The magnetic extracted iron sand was then sieved using a 200-mesh test sieve to obtain the iron sand bulk. Following that, the iron sand bulk was characterized.

The elemental compositions were analyzed using MiniPal 4 (MP4) EDXRF spectrometer. The X-ray diffraction pattern was collected using X-ray diffractometer PANalytical X-Pert Pro-MPD (PANalytical, Almelo, The Netherlands). Qualitative analysis of the crystal structure was identified with the Crystalography Open Database (COD) using the Match! Software [19]. The remanent magnetization, saturation magnetization, and coercivity were characterized using a vibrating sample magnetometer (VSM) OXFORD 1.2 H machine (Oxford Instrument, Oxfordshire, UK) with an applied magnetic field between $-10 \mathrm{kOe}$ and $+10 \mathrm{kOe}$. 


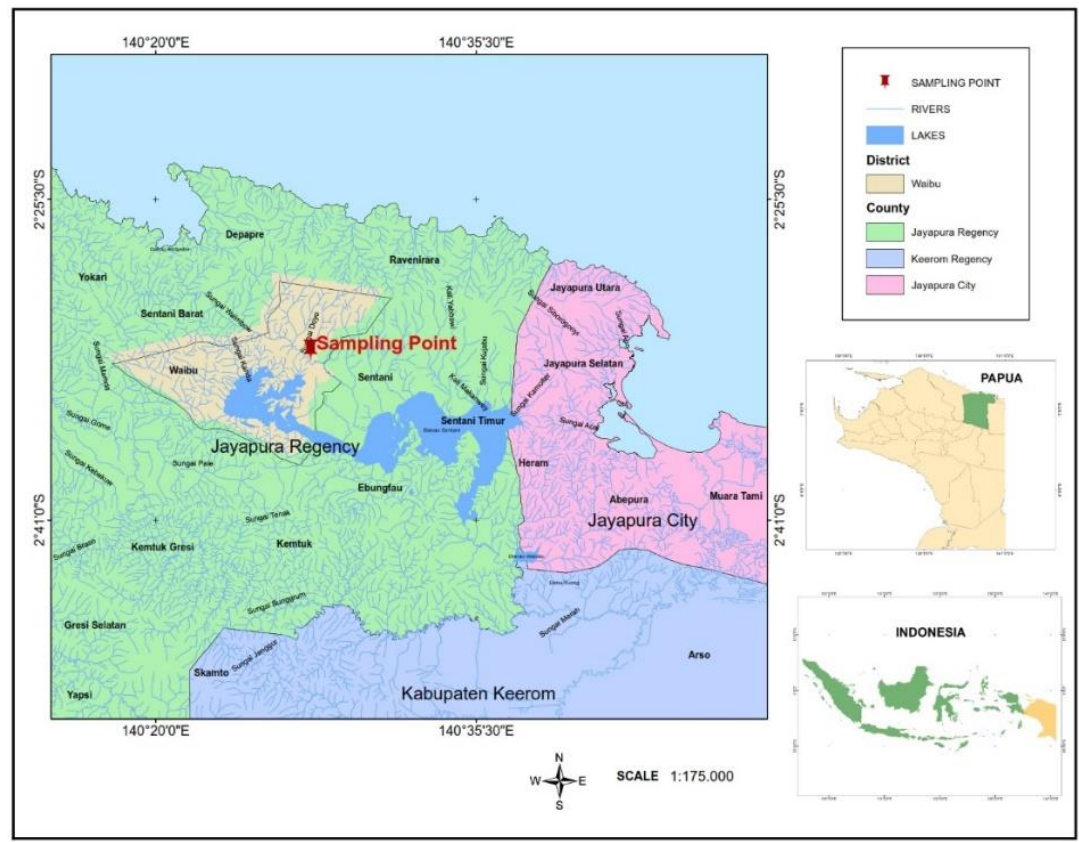

Fig. 1. Map of sampling point, Waimbow River at Waibu District, Jayapura Regency, Papua Province

\section{Results and Discussion}

The elemental compositions of the iron sand samples analyzed using X-ray fluorescence were shown in Table 1. The Fe element is the most dominant magnetic element, together with a small composition of other transition elements which also have magnetic properties, such as $\mathrm{Cr}$, $\mathrm{Ni}, \mathrm{Mn}, \mathrm{Ti}, \mathrm{Re}$, and $\mathrm{V}$. The non-magnetic Si element is the second dominant element, followed by the Ca element. Overall, this composition shows the typical characteristic type of natural iron sand $[12,13]$.

$\underline{\text { Table 1. Elemental compositions of iron sand from Waimbow River, Jayapura }}$

\begin{tabular}{cc}
\hline Elements & Composition (\%) \\
\hline $\mathrm{Fe}$ & 75.46 \\
$\mathrm{Si}$ & 16.00 \\
$\mathrm{Ca}$ & 4.77 \\
$\mathrm{Cr}$ & 1.41 \\
$\mathrm{Ni}$ & 1.24 \\
$\mathrm{Mn}$ & 0.43 \\
$\mathrm{Ti}$ & 0.41 \\
$\mathrm{~K}$ & 0.34 \\
$\mathrm{Cu}$ & 0.17 \\
$\mathrm{Re}$ & 0.09 \\
$\mathrm{~V}$ & 0.08 \\
$\mathrm{Zn}$ & 0.06 \\
$\mathrm{Rb}$ & 0.03 \\
\hline
\end{tabular}

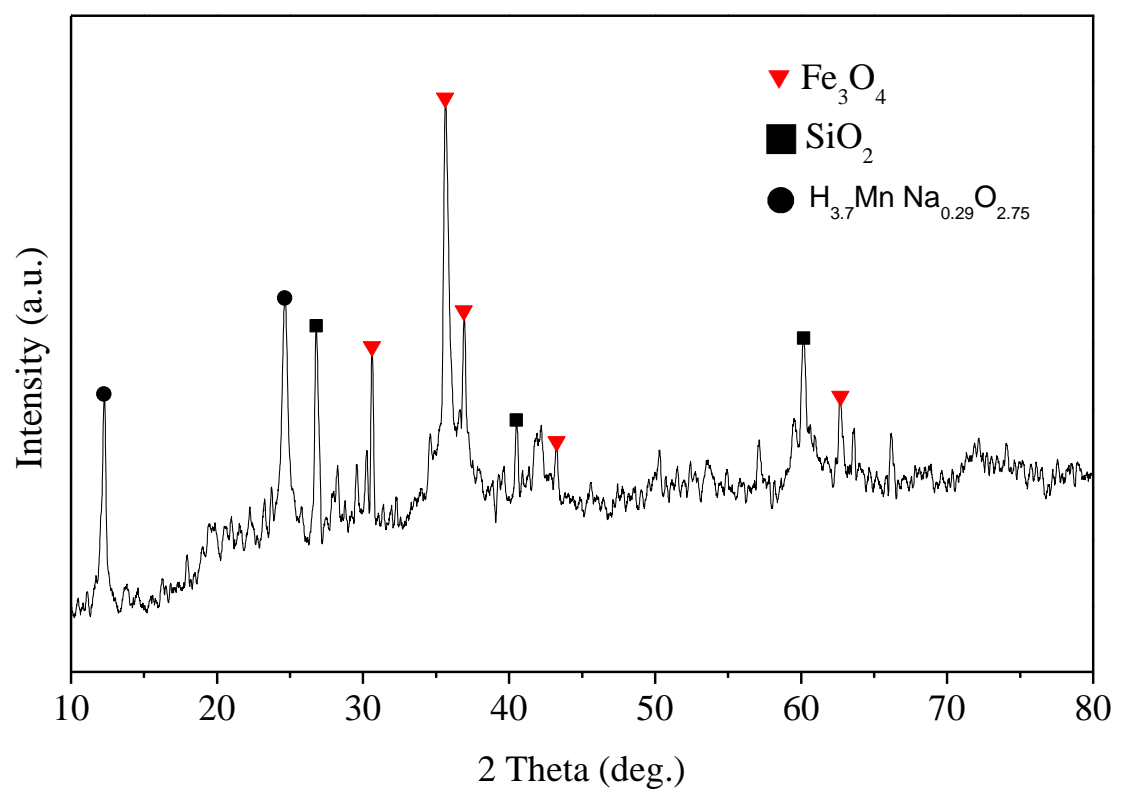

Fig. 2. X-ray diffraction pattern of iron sand from Waimbow River, Jayapura 
To confirm the magnetic properties of the iron sand samples, the hysteresis curve was measured at room temperature of the iron sand, as shown in Figure 3. The curve showed a hysteresis loop with a high saturation magnetization of 27.8, a remanent magnetization of 2.34 and a coercive field of 21.3. Furthermore, the hysteresis curve shows a narrow curve area, indicated that the iron sand is a typical soft magnetic material [20]. The low coercivity and paramagnetic-like behavior was known as the typical hysteresis curve of commercial magnetite [21]. Hence, the magnetic properties of the iron sands from Waimbow River, Jayapura arise from the magnetite mineral contained in it. However, the narrow curve area may be caused by the presence of impurities phase [21], such as quartz and Birnessite. The crystal phase and magnetic characterization of the river iron sand from Jayapura was found to be similar to that of the coastal iron sand from Sarmi, which is dominated with magnetite $\left(\mathrm{Fe}_{3} \mathrm{O}_{4}\right)$ and exhibits soft magnetic properties. This feature may suggests several magnetic applications, such as magnetic material for magnetic tape, magnetic speaker, magnet electric motors and others [5].

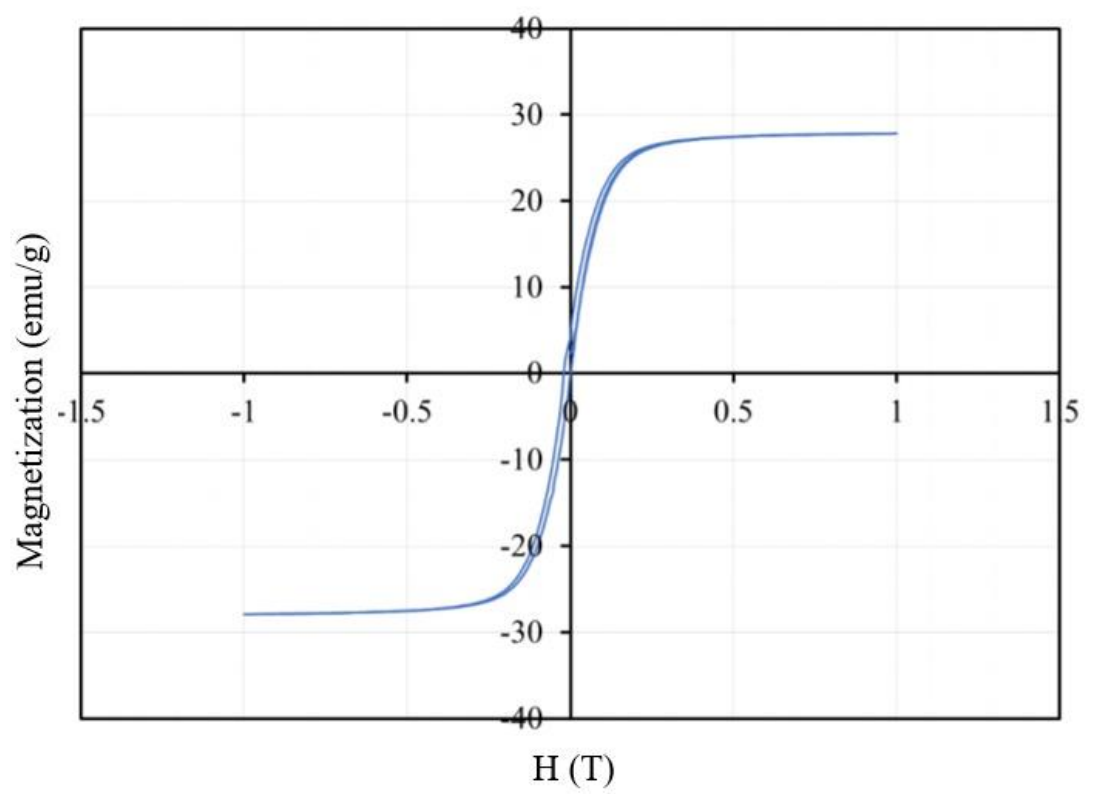

Fig. 3. Hysteresis curve of iron sand from Waimbow River, Jayapura

Notably, the iron sand on coastal Sarmi also strongly indicates that the iron sand originates from the river, namely the Tor River. The Waimbow River has a natural environment, not a densely populated areas, suggested that the source of magnetic minerals in the iron sand were mainly a lithogenic magnetic mineral [22]. Further study on the magnetic properties of the iron sand along the Waimbow River may be needed to verify the origin of the iron sand formation in the northern Papua.

\section{Conclusions}

Iron sand extracted from the Waimbow River, Waibu District, Jayapura regency, Papua contains Fe (75.46 \%) and Si (16.00 \%) as the predominant elemental contents. The X-ray diffraction pattern also confirmed the presence of magnetite, quartz, and birnessite polycrystalline phases. The hysteresis curve parameter measured at room temperature shown that the extracted iron sand from Jayapura is a soft magnetic material with a high saturation magnetization of 27.8 , a remanent magnetization of 2.34, and a coercive field of 21.3.

\section{References}

[1] S. Rochani, S. Sariman, R. I. Anugrah, and P. Pramusanto, “The current status of iron minerals in Indonesia," Indones. Min. J., vol. 11, no. 2, pp. 1-17, 2008.

[2] R. M. Cornell and U. Schwertmann, The iron oxides: structure, properties, reactions, occurrences and uses. John Wiley \& Sons, 2003.

[3] G. C. Novala, K. H. Kirana, S. J. Fajar, and S. Bijaksana, "Testing the effectiveness of mechanical magnetic extraction in riverine and lacustrine sediments," in Journal of Physics: Conference Series, 2019, vol. 1204, no. 1, p. 12085.

[4] S. Zulaikah, N. Mufti, A. Fuad, and L. D. Dwi, "Effect of mechanical milling on particle size, magnetic susceptibility and dielectric of synthetic toner colorant magnetite extracted from Indonesian iron sand," in AIP Conference Proceedings, 2014, vol. 1617, no. 1, pp. 156-160.

[5] T. Rusianto, M. W. Wildan, K. Abraha, and K. Kusmono, "The potential of iron sand from the coast south of Bantul Yogyakarta as raw ceramic magnet materials," J. Teknol., vol. 5, no. 1, pp. 62-69, 2012.

[6] T. Rusianto, M. W. Wildan, K. Abraha, and K. Kusmono, "Iron sand as renewable resource for production magnetic nano particles materials," 2013.

[7] N. Mufti, T. Atma, A. Fuad, and E. Sutadji, "Synthesis and characterization of black, red and yellow nanoparticles pigments from the iron sand," in AIP Conference Proceedings, 2014, pp. 165-169, doi: 10.1063/1.4897129.

[8] A. Yulianto, S. Bijaksana, and W. Loeksmanto, "Comparative study on magnetic characterization of iron sand from several locat ions in Central Java," Indones. J. Phys., vol. 14, no. 2, pp. 63-66, 2003.

[9] H. Kurnio, "Review Of Coastal Characteristics Of Iron Sand Deposits in Cilacap Central Java,” Bull. Mar. Geol., vol. 22, no. 1, pp. 35-49, 2016.

[10] F. Mufit, H. A. Fadhillah, and S. Bijaksana, "Kajian tentang Sifat Magnetik Pasir Besi dari Pantai Sunur Pariaman Sumatera Barat," J. Geofis. Bandung, 2006.

[11] M. Rianna et al., “Characterization of Natural Iron Sand From Kata Beach, West Sumatra With High Energy Milling (Hem)," J. Nat., vol. 18, no. 2, pp. 97-100, 2018.

[12] O. Togibasa, S. Bijaksana, and G. C. Novala, "Magnetic properties of iron sand from the Tor River Estuary, Sarmi, Papua," Geosciences, vol. 8, no. 4, p. 113 , 2018.

[13] O. Togibasa, M. Akbar, A. Pratama, and S. Bijaksana, "Distribution of magnetic susceptibility of natural iron sand in the sarmi coast area," in Journal of Physics: Conference Series, 2019, vol. 1204, no. 1, p. 12074.

[14] E. Haryati and K. Dahlan, "Potential of iron sand from betaf beach, sarmi regency and river sand from Doyo, Jayapura Regency, Papua as Basic Materials of mortar as nuclear radiation shielding," in Journal of Physics: Conference Series, 2018, vol. 997, no. 1, p. 12043.

[15] E. Haryati, K. Dahlan, and S. P. Wirman, "Karakterisasi Dan Sifat Kemagnetan Pasir Besi Ekstraksi Asal Pantai Betaf Sarmi, Papua," Phot. J. Sain Dan Kesehat., vol. 9, no. 2, pp. 238-241, 2019.

[16] R. Rochmawati and A. Yunianta, "Soil Characteristics in the Yetni Yahukimo River Area," in IOP Conference Series: Earth and Environmental Science, 2021, vol. 841, no. 1, p. 12007.

[17] R. M. Parinussa, “The Influence of Mining Activity of Material Group C on Jayapura," Institut Teknologi Sepuluh November, 2002.

[18] D. Padmalal and K. Maya, "Impacts of River Sand Mining," 2014, pp. 31-56.

[19] S. Gražulis et al., “Crystallography Open Database - an open-access collection of crystal structures," J. Appl. Crystallogr., vol. 42, no. 4, pp. 726-729, Aug. 2009, doi: $10.1107 /$ S0021889809016690.

[20] Y. E. Gunanto, M. P. Izaak, E. Jobiliong, L. Cahyadi, and W. A. Adi, "High purity Fe304 from local iron sand extraction," in Journal of Physics: Conference Series, 2018, vol. 1011, no. 1, p. 12005. 
[21] M. Ahmadzadeh, C. Romero, and J. McCloy, “Magnetic analysis of commercial hematite, magnetite, and their mixtures," Aip Adv., vol. 8, no. 5, p. 56807, 2018.

[22] S. Zulaikah, D. Sisinggih, Y. Bungkang, Z. Dani, and M. D. Ong, "Magnetic susceptibility, chemical element content and morphology of magnetic mineral in surface sediment of Kamp Walker and Hubay rivers as an inlet of Sentani lake, Papua-Indonesia," in AIP Conference Proceedings, 2017, vol. 1861, no. 1, p. 30010. 